\title{
Age Estimation with Smartphone: Is It Reliable for Forensics Identification?
}

\section{Estimasi Usia dengan Smartphone: Apakah Dapat Diandalkan dalam Identifkasi Forensik?}

\author{
Mieke Sylvia Margaretha Amiatun Ruth, Novita, Levina Gita, Arofi Kurniawan, Haryono Utomo
}

Department of Forensic Odontology, Faculty of Dental Medicine, Universitas Airlangga, Surabaya, Indonesia

E-mail: Miekesud@gmail.com

\begin{abstract}
Age estimation is one of the important components in forensic science used for personal identification, biological profile reconstruction, and help narrowing the search possibilities. Age estimation can be done by various methods and biological evidence, such as the human face. The human face is one of biometrics that provides a variety of information. The purpose of this article is to evaluate the accuracy and reliability of age estimation with face using smartphone for forensic identification based on previous studies and experiences. Age estimation by face is based on age progression that causes attrition and degeneration on soft tissue. With the development of technology, age estimation by face can be done with applications or websites on smartphone. In general, the utilization of smartphone can reduce waste, pollution, research cost and easier to save and share. A lot of applications have been developed and free to download. Unfortunately, the accuracy of its results is unknown. In conclusion, the applications for age estimation on smartphone give quiet good results and can be used as a supporting tool to estimate age in forensic identification.
\end{abstract}

Key words: Age estimation, human face, smartphone

\begin{abstract}
Abstrak
Estimasi usia merupakan salah satu komponen penting dalam ilmu forensik yang berperan dalam proses identifikasi, rekonstruksi profil biologi dan membantu mempersempit pencarian. Estimasi usia dapat dilakukan dengan berbagai metode dan bukti biologis, salah satunya adalah dengan wajah. Wajah manusia adalah biometrik yang menyediakan berbagai infomasi penting. Tujuan artikel ini adalah untuk mengevaluasi akurasi estimasi usia dengan wajah melalui smartphone dan mengetahui apakah aplikasi-aplikasi tersebut dapat digunakan dalam identifikasi forensik.Estimasi usia melalui wajah didasari oleh prinsip progresivitas usia yang menyebabkan atrisi dan degenarasi pada jaringan lunak. Seiring dengan perkembangan teknologi, estimasi usia melalui wajah dapat dilakukan dengan menggunakan aplikasi atau website di smartphone. Secara umum, penggunakan smartphone dalam bidang forensik mampu mengurangi polusi, mengurangi biaya, mempermudah penyimpanan dan mudah dibagikan. Berbagai aplikasi estimasi usia telah dikembangkan dan tersedia secara gratis pada smartphone, tetapi akurasi dari program tersebut masih belum banyak diketahui. Kesimpulan tinjauan artikel ini adalah estimasi usia menggunakan aplikasi pada smartphone memberikan hasil yang cukup baik dan dapat digunakan sebagai sarana pendukung dalam estimasi usia pada identifikasi forensik.
\end{abstract}

Kata kunci: Estimasi usia, wajah, smartphone

\section{INTRODUCTION}

The human face is one of biometrics that can give a wide variety of information, such as identity, age, gender, emotion, and ethnicity. ${ }^{1,2}$ Each person has a different facial characteristic and no human face is like another, even in monozygotic twins. A lot of factors influence human face characteristics, such as environment, health conditions, lifestyle, and genes. The human face is also affected by facial expression, head profile, occlusion and aging. ${ }^{3}$ Because of its individualizing characteristics, the human face is used for identification purposes. ${ }^{2,4}$ The human face as a tool for identification has been used in real-world applications. For examples are in a passport, driver license, and criminal investigation. ${ }^{5}$

For the past few years, analysis research is being led to an area of facial appearance as an age estimator. Facial appearance provides the most essential information about age. Age estimation is one important component of forensic medicine which is challenging and requires an interdisciplinary approach. ${ }^{6,7}$ Age esti- 
mation helps the investigator in narrowing the search possibilities for unidentified individuals and is used for legal purpose. ${ }^{8}$ Estimation of age from the human face, called age perception, is based on age progresssion that happens when human gets older. Age progression is generally caused by attrition and degeneration of soft tissue and can be seen in alteration of skin texture, face structure, and skin colour. ${ }^{9,10}$

A lot of studies about age perception have been done digitally in the last 20 years. Due to rapid advances in technologies, age estimation can be proceeded by face image and analysed in smartphone. ${ }^{3}$ The interference of smartphone makes the age perception easier, faster and can be used widely in every place. Smartphones' utilization is also part of green dentistry which helps reduces waste, pollutions, and research costs. Other benefits in using smartphone are the data can be saved easily and transmitted to another user. Application in smartphone for age perception has gained significant attention and a lot of applications are commercially available. Unfortunately, its accuracy is still unknown. This article will discuss a few applications and website in smartphone for age perception and assess the accuracy of the result.

Age estimation is one important component and crucial parameters in forensic science. It is used to reconstruct a biological profile, personal identifycation, and help to narrow the search possibilities. It is one of the important factors in biological identifycation in many forensic fields, such as forensic medicine, forensic odontology, and forensic anthropology. Age estimation of the living, and dead can be done with various methods such as dental, skeletal, histological and biochemical analysis. ${ }^{8,11}$

The need for age estimation has increased in the past few years. Age estimation is not only used to identify the deceased, it is also used to estimate the date of birth for living individuals who do not have birth certificate. ${ }^{12}$ Age estimation application for legal purpose can be used to indicates the adult status in criminal cases when the suspect's chronological age is unknown. $^{8}$

The human face conveys abundant information about age. The face appearance is closely related to the physical changes and influence by the aging process. Age progression is inevitable and systematically changes human face throughout the lifespan due to maturation, growth, and senescence. ${ }^{13,14}$ Age progression effects on the face are related to alteration of the skin, soft tissue, and skeleton. It can be seen as facial wrinkles, changes in skin texture, skin colour and, geometric facial features. ${ }^{15,16}$

Aging effects on the human face may come in diverse ways. It has been reported that each person has a different aging pattern, and it depends on several factors, such as genetics, dietary habits, ethnicity, environment, and level of stress. Facial aging also differs in every stage of life. ${ }^{17}$ Histologically, facial aging can be divided into intrinsic aging and extrinsic aging and both of them also occur in all body tissue. Intrinsic aging is related to physiologic and histological changes that cause cellular apoptosis and another genetic transformation. Intrinsic aging leads to changes in epidermal tissue and epidermal cell, decrease in melanocytes and Langerhans cells, reduced number of mast cells, and fibroblast. Different from intrinsic aging, extrinsic aging is associated with external factors such as dehydration, extreme temperature, injury, environmental toxins, and exposure ultraviolet (UV) rays. The common changes in extrinsic aging are epidermis thickening, dermaepidermal junction flattening, and increasing of hyperplastic fibro-blasts. $^{18}$

During the growth period, age progression can be seen on the transformation of the head and face and it is called "Cardioidal strain". Head and face transform remarkably and can be recognized as the differences between age easily. On the other side, in 20 years of life, craniofacial transformations are fewer than soft tissue changes. ${ }^{10}$ Between 20 to 60 years of life, the major alteration can be seen with the decrease of soft tissue thickness. ${ }^{19}$ Biologically, collagen underneath the skin also decreases as the human gets older. Loss of collagen underneath the skin is characterized by darker skin, thinner, leathery, and less elastic skin. ${ }^{3}$

The development of digital technologies and communications has entirely changed human lifestyle. Digital technologies have replaced many traditional methods and removed a lot of barriers associated with conventional media. It also has an impact on forensic science. Forensic science can be described as identification, collection, analysis, and explanation of evidence with the appliance of scientific or technical approaches. ${ }^{20} \mathrm{~A}$ lot of technologies have been improved and used in forensic science in recent years and it helps to improve the sensitivity and facilitate forensic investigation. ${ }^{21}$

Utilization of technology in forensic science, called digital forensic science, can be defined as investigations or criminal proceeding which uses technology as a method to obtain and analyse all digital evidence. Currently, digital evidence processing can be done with portable electronics such as smartphones. It becomes the primary focus of interest to researchers and examiners. ${ }^{22}$ The use of portable electronic devices has increased significantly and gained popularity for forensic purposes. As well as computers, smartphones also have a high level of capability and can be used to analyse, recover, and manage criminal investigation's data. ${ }^{23}$ 
Due to development of information technology, smartphone is undoubtedly become one important part of human's daily lives. With so many features inside, smartphone is used in many field, including forensic field. ${ }^{24}$ One of application of smartphone utilization in forensic field is automatic face image age estimation system. Automatic face image age estimation system consists of two parts, namely face detection and age estimation. The purpose of face detection is to recognize and localize the face in an image. $^{16}$

There are three categories of human face extraction method for age estimation. First method is aging pattern subspace (AGES). AGES method is statisticalbased approach that use Principle Component Analysis (PCA) from the image. The second category is based on appearance. The primary features appearances which are used to analyse are eyes, nose, mouth, and chin. This method also uses wrinkle and do a measurement to estimate age. The third category is a widely used method which is based on comprises frequency approaches. ${ }^{16}$

A lot of age estimation applications and websites are commercially available and free to use. Age estimation applications on IOS and Android systems are different. Some applications are only compatible or available on Android or iOS.

PhotoAge Live is an application for age estimation available on the iOs system and released in 2010 under a company named Percipo and compatible for iPhone, iPad, and iPod Touch. ${ }^{25}$ This application is able to calculate age from human face by using special software algorithms to analyse biometric landmarks. ${ }^{26}$ The users are allowed to use a photo from the library or take a new photo from the app.

How Old Do I Look - Age Camera is another application for age estimation released by Lucky Studio Games available on the Android system. It was published in 2015 and has been downloaded over 500.000 times in playstore. This application gives the user options to take a new picture or load an existing photo on the gallery. This application is designed with $\mathrm{AI}$ and able to recognize all faces in the picture quickly. ${ }^{27}$

Check My Age is an application for biometric face detection and designed for age estimation available on the Android system. This app was released in 2016 and powered by Neurotechnology. Neurotechnology company itself was founded in Lithuania in 1990 and had released a lot of products related to biometric identification such as fingerprints, palm print, faces, irises and voices. All softwares they designed are based on Deep Neural Network (DNN), and other artificial intelligence-powered technologies ${ }^{28}$. According to the app description, this program was built base on face recognition algorithms and Sky Biometry API. To provide an accurate age estimation result, this program use algorithm trained on more than 100.000 samples. $^{29}$

For using this app, the user can use any smartphone or tablet with an internet connection. This app will automatically detect the face in a photo and calculates the age estimation. The user can take a new picture from the app or use a picture that is already taken in the user's phone. This app also can analyse a group picture and show each person's age estimation. To get a better age evaluation result, the user's face in a frame must be large and clear enough. The users are able to share the result on social media such as Facebook, Twitter, email, Instagram, and many more. ${ }^{29}$

Different from the previous age estimator application, How-Old.net is a website powered by a company under Microsoft, called Microsoft Azure. Based on Microsoft Azure website, How-Old.net use Azure ML Face Detection API's to predict the age and gender of any faces in the picture. The developers built this website with newly released Face Detection Matching Learning API's and use Azure Stream Analytics to analyse data in real-time. Since the day it was released, this website has become one of the internet sensations and gained a lot of attention. In less than a week, 33 million users and 236 million images had been uploaded on the website. Compared to previous applications, this website does not provide any option to take a picture. The users must take a picture first with their camera and then upload on the website. How-Old.net also accepts a group picture and able to analyse all person's ages recognized in the picture. ${ }^{30}$

\section{DISCUSSION}

Facial age estimation through smartphone applications has gained a lot of interest and many potential applications have been established. All age estimation applications by face are expected to change human performance equally or even surpass human performance. Regarding the accuracy of age estimation application, only a few studies have been done to evaluate and count its accuracy.

Sebastian et al $(2015)^{26}$ evaluated one of the age estimation application called PhotoAge Live. Their study tested the application and compared it with the chronological and biological age estimation. This study also tried 2 different facial expressions, neutral face and smiling face with teeth, to evaluate the influence of facial expression. Based on statistical analysis, there were no statistically significant differences between PhotoAge results and the true mean age of the 
samples or age prediction from human raters. There was only 1-year average differ-rence and can be considered close enough to the chro-nological age of the samples. However, the appli-cation tends to give younger age estimation on a neu-tral face than a smiling face. Sebastian et al $(2015)^{26}$, concluded PhotoAge application can be used as a solid objective or valuable asset to estimate age in the forensic field.

Different study about age estimation by smartphone application reported by Machado et al (2017) ${ }^{31}$. Machado et al $(2017)^{31}$ use another application called How Old Do I Look?-Age Camera. This study compared age estimation from the application with the chronological age and evaluate its correlation. This study also used neutral facial expression and smiling faces. The result revealed there is no difference age estimation between facial expressions and showed a quite good correlation for men. Unfortunately, they found a low correlation of age estimation for female subjects. ${ }^{31}$

There is no study or research about the accuracy of How Old.Net and Check My Age. We tried both applications and used 2 different facial expressions (Neu-

\section{REFERENCES}

1. Hu P, Ning H, Qiu T, Xu Y, Luo X, Sangaiah AK. A unified face identification and resolution scheme using cloud computing in internet of things. Future Gener Comp Sy 2018; 81:5 82-92.

2. Othmani A, Taleb AR, Abdelkawy H, Hadid A. Age estimation from faces using deep learning: A comparative analysis. Comput Vis Image Underst 2020; 196.

3. Angulu R, Tapamo JR, Adewumi AO. Age estimation via face images: a survey. Eurasip J Image Vide 2018; 2018(42): 2-35.

4. Leipner A, Obertová Z, Wermuth M, Thali M, Ottiker T, Sieberth T. 3D mug shot-3D head models from photogrammetry for forensic identification. Forensic Sci Int 2019; 300: 6-12.

5. Han H, Otto C, Jain AK. Age estimation from face images: Human vs. machine performance. Int Conf Biometrics 2013: 37(6): 1148-61

6. Nayak SD, George R, Shenoy A, Shivapathasundaram B. Age Estimation in Forensic Dentistry- A Review. Int J Sci Res 2014; 3(4): 333-8.

7. Santoro V, De Donno A, Marrone M, Campobasso C Pietro, Introna F. Forensic age estimation of living individuals: A retrospective analysis. Forensic Sci Int 2009; 193(1-3): 129.

8. Duangto P, Janhom A, Prasitwattanaseree S, Mahakkanukrauh P, Iamaroon A. Age estimation methods in forensic odontology. J Dent Indonesia 2016; 23(3): 74-80.

9. Jana R, Datta D, Saha R. Age estimation from face image using wrinkle features. Procedia Comput Sci 2015; 46: 1754-61. tral face and smiling face with teeth). Based on our experiences, How Old.Net website showed 3 years average differences and 4 years average differences for Check My Age from average chronological age. The facial expression also influences age estimation result and smiling face showed older age estimation. We also tried PhotoAge Live and How Old Do I Look? -Age Camera and both applications give aquite good result.

Within the limitations of this study, we conclude that applications and website used to estimate age on the smartphone showed quite good results and can be used as a supporting tool in the forensic field. However, further study should be conducted to compare the accuracy of each application with some clearer selection criteria applied in a bigger sample size and varieties age groups. For example, the photoshoot technique, the smartphone used regarding the camera resolution, different angles or positions, and also try to compare the result between the photo from the gallery or photo taken by the app. It would be good if the next study also compares the differential expression result, other than smiling face and neutral face.

10. Imai T, Okami K. Facial cues to age perception using three-dimensional analysis. PLoS One 2019; 14(2): 1-18.

11. Ellingham S, Garriga JA. Age estimation: A multidisciplinary approach. Garriga JA, Ed. USA: Elsevier Inc 2019: 1-15.

12. Divakar KP. Forensic odontology: The new dimension in dental analysis. Int J Biomed Sci 2017; 13(1): $1-5$.

13. Porcheron A, Mauger E, Russell R. Aspects of facial contrast decrease with age and are cues for age perception. PLoS One 2013; 8(3): 1-8.

14. O'Neil SF, Webster MA. Adaptation and the perception of facial age. Vis cogn 2011; 19(4): 534-50.

15. Deepa A, Sasipraba T. Age estimation in human face by fractal directional code method. Int $\mathrm{J}$ Electr Eng Educ 2019; 0(0): 1-14.

16. Lin CT, Li DL, Lai JH, Han MF, Chang JY. Automatic age estimation system for face images. Int $\mathbf{J}$ Adv Robot Syst 2012; 9(216): 1-9.

17. Yadav D, Singh R, Vatsa M, Noore A. Recognizing age-separated face images: Humans and machines. PLoS One 2014; 9(12): 1-22.

18. Fitzgerald R, Graivier MH, Kane M, Lorenc ZP, Vleggaar D, Werschler WP, et al. Update on facial aging. Aesthetic Surg J 2010; 30(Suppl 1): 11S-24S.

19. Windhager S, Mitteroecker P, Rupić I, Lauc T, Polašek $O$, Schaefer K. Facial aging trajectories: A common shape pattern in male and female faces is disrupted after menopause. Am J Phys Anthropol 2019; 169(4): 678-88.

20. Arshad H, Jantan A Bin, Abiodun OI. Digital 
forensics: Review of issues in scientific validation of digital evidence. J Inf Process Syst 2018; 14(2): 346-76.

21. Fakiha B. Technology in forensic science. J Sci Technol 2019; 7: 1-10.

22. Goodison SE, Davis RC, Jackson BA. Digital evidence and the U.S. criminal justice system. Prior Crim Justice Needs Initial 2015; 1-32.

23. Hikmatyar FG, Sugiantoro B. Digital Forensic analysis on android smartphones for handling cybercrime cases. IJID 2019; 7(2): 19-22.

24. Kausar F. New research directions in the area of smart phone forensic analysis. Int $\mathbf{J}$ Comput Networks Commun 2014; 6(4): 99-106.

25. Percipo I. PhotoAge Live - How Old Do You Really Look?. <https://apps.apple.com/us/app/photoagelive-how-old-do-you-really-look/id391310821> (1 Agustus 2020).

26. Patzelt SBM, Schaible LK, Stampf S, Kohal RJ. Software-based evaluation of human age: A pilot study. J Esthet Restor Dent 2015; 27(2): 100-6.

27. Lucky Studio Games. How old do I look - Age camera <https://play.google.com/store/apps/details ?id=com.hust.facedetect $>$ (19 Mei 2020).

28. Malickas A. Technology for your Application Company information <www.neurotechnology.com \%0AMegaMatcher> (19 Mei 2020).

29. Pavelas.Check my afer app - Great tool for age estimation <https://skybiometry.com/check-age-appgreat-tool-age-estimation/> (18 Mei 2020).

30. Gaurav M. How-old.net: Augmenting virality in real time with batch analytics using data factory <https:// azure.microsoft.com/en-us/blog/how-old-netaugmenting-virality-in-real-time-with-batchanalytics-using-data-factory/> (19 Mei 2020).

31. Machado RAL, Dezem TU, Bruni AT, Alves da Silva RH. Age estimation by facial analysis based on applications available for smartphones. J Forensic Odontostomatol 2017; 35(2): 55-65. 